\title{
Development of Smartphone-based Environmental Education Program for Pro-environment Behavior of Company Employees Around Citarum Watershed
}

\author{
Rita Istiana*, Rita Retnowati, Sutanto \\ Lecture \\ Pakuan University \\ Bogor, Indonesia \\ *rita_istiana@unpak.ac.id
}

\author{
Doni Junia Darmasakti \\ Post Graduate Student \\ Pakuan University \\ Bogor, Indonesia
}

\begin{abstract}
This research aims to develop smartphone-based environmental education programs for employees in citarum watershed. This research is a preliminary study that is included in stages 1 to 3 in the development procedure Research and Development (R\&D) of Borg and Gall, namely Research and information collecting, Planning, Developing a preliminary form of the product. The study was conducted from January to April 2020. Participants in this study were company employees in the Citarum River Basin, Purwakarta Regency, West Java. The sampling technique used in this study was random sampling. The instrument used to collect research data was a questionnaire. The instrument used in product development is the validation instrument of media experts and environmental material experts. Data were analyzed quantitatively and qualitatively. Preliminary research results show that the pro-environment behavior of employees was influenced by $29.2 \%$ perception of environmental policies, $16.8 \%$ understanding of environmental pollution, $20.1 \%$ of corporate environmental responsibility, and $33.7 \%$ is influenced by the perception of ecological threats. The results of the material expert validation show that the product developed has a score of 4 for relevance; 4.5 for accuracy; 4 for completeness of presentation and material, 3.5 for curiosity; 4.5 for the encouragement of interaction; and 4 to encourage employees to build their knowledge (scale 1-5). The results of the validation media experts showed that the product developed had a score of 4 in the presentation of the application, 3.5 for language and typography, and $\mathbf{4}$ for functions and benefits (scale 1-5). The Android-based environmental education program for employees in the Citarum River Basin was developed as a model of employee environmental education recommendations to improve employee pro-environment behavior.
\end{abstract}

Keywords-Citarum watershed, environmental education proenvironment employee behavior

\section{INTRODUCTION}

The Citarum River in West Java is one of the most polluted rivers in Indonesia. The Citarum River is a source of drinking water supply for West Java and DKI Jakarta Provinces. Along the watershed, Citarum has many industrial manufacturing areas such as textiles, chemicals, paper, leather, metals, pharmaceuticals, food, and beverage products. This condition causes the Citarum River to be polluted by 20,462 tons of organic and inorganic waste. The industrial world is expected to immediately commit to ending the disposal of hazardous and toxic chemicals (B3) through a clean production program. For this to happen, factory / industrial entrepreneurs need to have pro-environmental awareness and behavior. According to Ruepert, Keizer, \& Steg [1] companies that have Corporate Environmental Responsibility need to stimulate their employees to behave pro-environmentally.

Pro-environmental behavior is an action that is taken deliberately to reduce the negative impact on the environment and is operationalized as a daily behavior that concerns environmental conservation [2]. In research conducted by Pothitou, Hanna, \& Chalvatzis [3] identified the importance of implementing an environmentally responsible strategy to promote pro-environmental behavior. Environmental problems are not a problem for one country alone but have become the responsibility of all countries in the world. One of the ways that can reduce natural damage is through efforts to cultivate awareness, concern, and human understanding of the environment, namely through environmental education [4].

Environmental education or education has an important role in overcoming the problem of environmental damage and is an important means of producing human resources who can implement the principles of sustainable development. As stated by Retnowati, Istiana, \& Suhardi [5] that currently, the need for environmental education is very critical. Environmental education is carried out as an effort to increase public understanding and concern in seeking solutions and prevention of environmental problems [6].

Environmental problems that are commonly found in human life are environmental pollution problems. Air, soil, water, and noise pollution will take a long time to get clean again. The industrial sector and motor vehicle fumes are the main sources of air pollution. Heavy metals, nitrates, and toxic plastics are responsible for pollution in cities, on the other 
hand, factory waste, household waste also pollutes the waters including there, rivers, and oceans [7]. Environmental education is carried out as an effort to increase public understanding and concern in seeking solutions and prevention of environmental problems [6].

Education can be done formally through the world of education and informally for the community. Research conducted by Tsai, Jou, Wang, \& Huang [8] proves that specially designed teaching materials are very helpful in improving student creativity and scientific reasoning. The results also identified a strong correlation between technical creativity and scientific reasoning. Mobile learning is a type of learning where students obtain learning materials using wireless handheld devices such as cell phones, personal digital assistants (PDAs), wireless laptops, personal computers, and tablets that can be used anytime and anywhere [9]. According to Henri Kurniawan and Tri Shandika Jaya [10], Android is a Linux-based mobile device operating system that includes an operating system, middleware, and applications. Android provides an open pattern for developers to build applications.

To shape pro-environmental behavior, employees of a company need to have a good understanding of environmental pollution. Based on research conducted by Pothitou et al [3], shows that there is a positive influence of knowledge about the environment with the formation of pro-environmental behavior, thus employees of a company need to be provided with training that leads to an understanding of environmental problems. Based on the reasons above, an environmental education program was developed for employees by utilizing Android mobile learning media so that the educational process can run more effectively and efficiently because it can be done anytime and anywhere.

\section{RESEARCH METHODS}

This research was conducted on employees of industrial companies/factories around the Citarum watershed in Babakancikao District, Purwakarta Regency. The research subjects were employees of Indo Bharat Rayon (fabric factory). This research includes Research and Development with the Gall and Borg model. The procedural model steps are as follows: 1) Research and information collecting, 2) Planning, 3) Develop a preliminary form of product, 4) Preliminary field testing, 5) Main product revision, 6). Main field-testing main field testing. 7) Operational product revision, 8) Operational field testing, 9) Final product revision, 10) Dissemination and implementation. However, this article only discusses steps 1 to 3 , namely the development of the initial product form. The preliminary instrument used to collect research data was a questionnaire. The instrument contains questions and statements regarding perceptions of environmental policies, understanding of environmental pollution, corporate environmental responsibility, and perceptions of ecological threats. Initial product development uses expert validation, namely media experts and material experts. The data collection technique used focus group discussion with statement instrument types with a scale rating of 1-5 and open essays.
The instrument contains statements about the material content, language, and appearance of the media.

\section{RESULTS AND DISCUSSION}

\section{A. Research and Information Collecting}

Based on the results of preliminary research conducted, the strength of the relationship between perceptions of environmental policies and employee pro-environmental behavior is indicated by a correlation coefficient of 0.540 and a coefficient of determination of 0.292 . This shows that the employees' pro-environmental behavior is influenced by the perception of environmental policies by $29.2 \%$. This suggests that between perceptions of environmental policies and the proenvironmental behavior of employees has a moderate positive relationship, that the higher employee perceptions regarding environmental policies will be followed by an increase in employee pro-environmental behavior. Conversely, the lower the employees' perceptions regarding environmental policies, the lower the employee's pro-environmental behavior will be. The results of the research show a relationship between perceptions of environmental policies and pro-environmental behavior in line with Albrizio's study, 2016 which states that the application of environmental policies that affect the production process, reallocation of resources, capital investment, labor intensity, and innovation incentives has the aim of improving environmental conditions. Following the dependent variable studied, namely employee proenvironmental behavior where one part of it is reducing environmental damage that occurs. This is also supported by research conducted by Zhongju Liao, 2018 that for more than 25 years research has been carried out about environmental policies in China including 231 policies showing that it is true that environmental policies have an impact on environmental innovation for companies that continue to develop although of course, it is necessarily strengthened in terms of authority and operability of the environmental policy instrument.

In the next variable, the strength of the relationship between the understanding of environmental pollution and employee pro-environmental behavior is indicated by a correlation coefficient of 0.409 and a coefficient of determination of 0.168 . This shows that the pro-environmental behavior of employees is influenced by an understanding of environmental pollution by $16.8 \%$. This suggests that the understanding of environmental pollution with employees' pro-environmental behavior has a moderate positive relationship, that the higher the understanding of environmental pollution will be followed by an increase in employee pro-environmental behavior. Conversely, the lower the understanding of environmental pollution, the lower the employee's pro-environmental behavior.

The variable of corporate environmental responsibility has a correlation level of $\mathrm{r}=0.448$ on the pro-environmental behavior of company employees. The value of the coefficient of determination $\left(\mathrm{r}_{\mathrm{y} 1}{ }^{2}\right)=0.201$, this concludes that the variable of responsibility affects $20.1 \%$ of the pro-environmental 
behavior of company employees, while the rest comes from other variables not examined. Research [11] determines that pro-environmental behavior is influenced by knowledge of the environment and the distance between the place of residence or work and the surrounding natural conservation areas. So, if the Citarum watershed is designated as a nature conservation area, it will increase the pro-environmental behavior of company employees, or at least the government will intensify the Citarum Harum program, which must be campaigned to encourage corporate environmental responsibility. Research [12] explains that environmental responsibility greatly influences pro-environmental behavior.

The ecological threat perception variable on the proenvironmental behavior of company employees correlates 0.580 . The value of the coefficient of determination $\left(\mathrm{r}_{\mathrm{y} 2}{ }^{2}\right)=$ 0.337 , this concludes that the variable of responsibility affects $33.7 \%$ of the pro-environmental behavior of company employees, while the rest comes from variables not examined. Research [13] explains that employees 'pro-environmental behavior is related to employees' environmental attitudes. The environmental attitude in question is the desire to improve the pro-environmental behavior of company employees which is related to the employee variables autonomous motivation (AM) and controlled motivation (CM). In the study [11], it was explained that employees 'pro-environmental behavior is influenced by knowledge of the environment and the distance between employees' living areas and nature conservation areas. The closer to the residence, the awareness of employees about the perception of ecological threats. Based on the results of this study, efforts to improve the pro-environmental behavior of company employees can be stimulated by establishing the Citarum Watershed as a conservation area, or at least the government and Stake Holders related, campaigning and intensively running the Citarum Harum program that has been implemented.

\section{B. Planning (Planning)}

Based on the preliminary research above, to improve the pro-environmental behavior of employees around the Citarum river basin, an educational media is needed for employees to increase their understanding of the Citarum river and the problems that exist in the river. For this reason, the media is designed based on android or mobile learning so that it is easily accessible to all employees. The Citarum Education Media was designed as follows:

- Creating a Citarum Education Logo

- The name of the application is EduCitarum

- Creating a mobile learning/android-based media application so that it can be accessed on a cellphone

- The application menu includes Home, Introduction, Citarum River Watershed, Citarum Damage, Harum Citarum Program, Do and Don't, Pro-environmental behavior instruments, discussions and contacts
- The application menu can be accessed offline but for discussions, it must be online.

The details of the initial look at the android-based environmental education media application that has been built, before testing and validation by materials and media experts can be seen in figure 1 .

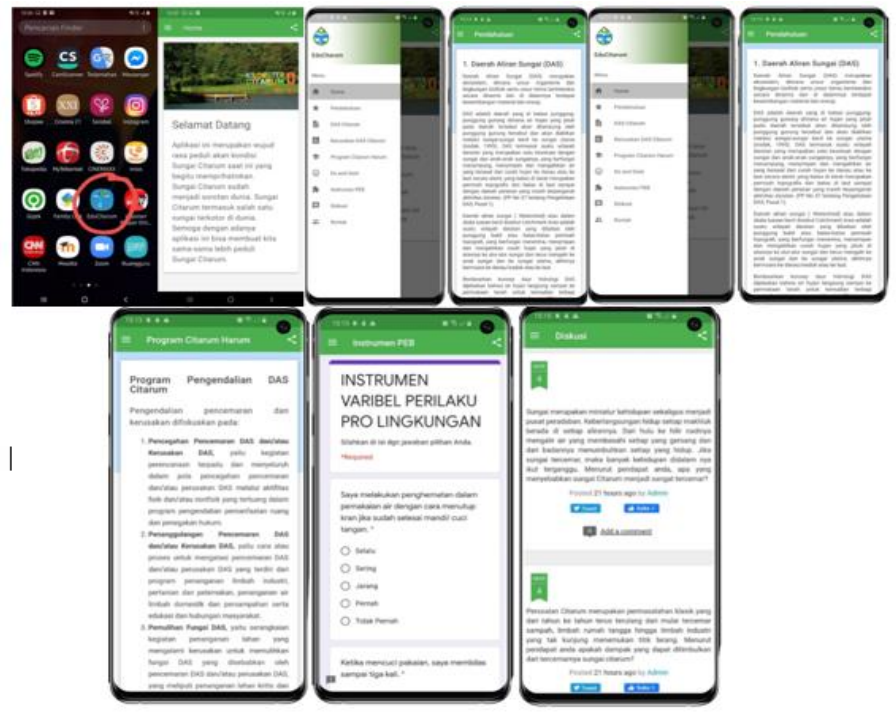

Fig. 1. Design of EduCitarum Educational Media.

\section{Develop a Preliminary Form of the Product}

The results of material expert validation show that the product developed has a score of 4 for relevance; 4.5 for accuracy; 4 for completeness of dishes and materials, 3.5 for curiosity; 4.5 for interaction encouragement; and 4 to encourage employees to build their knowledge (scale 1-5). The results of the media expert's validation show that the product developed has a score of 4 in the presentation of the application; 3.5 for language and typography; and 4 for functions and benefits (scale 1-5). So that an android-based environmental education program for employees in the Citarum river basin was developed as a model for employee environmental education recommendations to improve employee pro-environmental behavior.

An open essay questionnaire from media experts suggests that the images in the application are not too clear and have too much narrative so that the reader is easily bored. The results of an open essay questionnaire from material experts stated that the application was too dense in material and the language used was too scientific and not a popular language, so it was suggested to reduce the menu in the application and make it more concise and applicative. The application menu after revision includes Home, Introduction, Citarum Watershed, Do and Donts, Pro-environmental behavior instruments, Discussion, and contact. Revised input from media and material experts can be seen in Figure 2 below. Figure 2 explains the changed EduSea app based on advice from experts. 


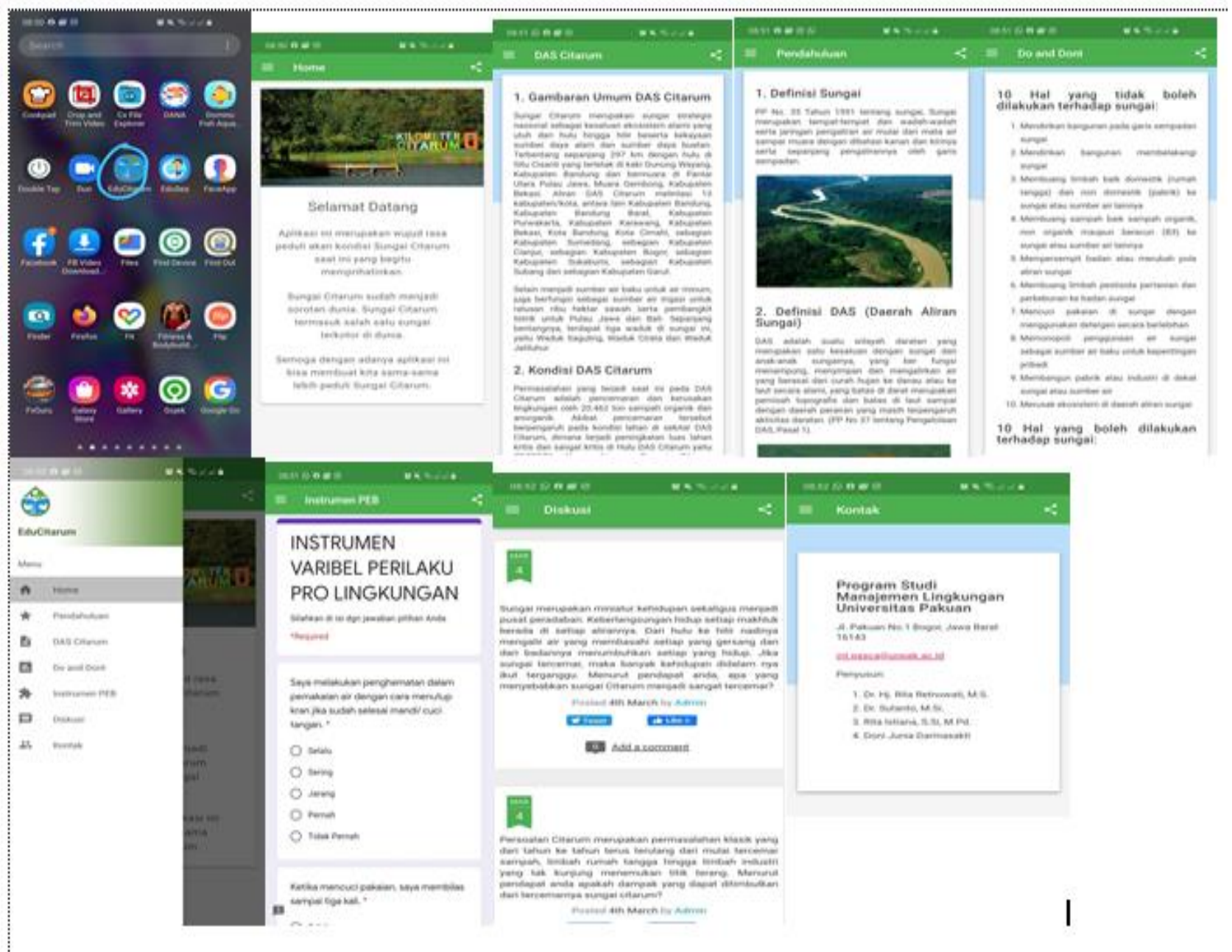

Fig. 2. Design of EduCitarum Educational Media After Revisi.

In the learning process, there is a shift from conventional methods to innovative methods that use a variety of sophisticated and modern learning media [14]. The existence of various kinds of learning media is expected to be able to create an effective and efficient learning process so that it can achieve educational goals. Learning media as a tool to deliver students' abilities in appreciating several abilities, knowledge, and attitudes in solving daily problems in the learning process [15]. Learning media that make use of cell phone technology is called mobile learning. Mobile learning is an alternative development of learning media. Mobile learning can be seen as a system that is seen as an effort to improve the quality of learning by trying to break through the limitations of space and time [16]. The increasing number of people who own and use mobile devices opens up opportunities for the use of mobile technology devices in education. The use of (mobile devices) in the learning process became known as mobile learning (mlearning) [17]. O'Malley [18] defines mobile learning as learning that learners (learners) do not stay in one place or learning activities that occur when learners make use of mobile technology devices. The presence of m-learning cannot replace e-learning (electronic learning the usual), let alone replace face-to-face learning in class. The presence of m-learning is intended as a complement to existing learning and provides opportunities for students to relearn less mastered material wherever and whenever. This certainly can provide a different experience in the learning process.

Android is a Linux-based operating system for mobile devices. Android is the most popular operating system in society because it has advantages such as nature open source which gives developers the freedom to create applications [19]. Android can simply be interpreted as the software used on devices mobile which includes the operating system, middleware, and key applications released by Google [EMS Teams, 2015].

\section{CONCLUSION}

The results of preliminary research indicate that the proenvironmental behavior of employees is influenced by $29.2 \%$ perceptions of environmental policies, $16.8 \%$ understanding of 
environmental pollution, $20.1 \%$ of corporate environmental responsibility which means that it illustrates that the company's role is to make rules or norms of pro-behavior. -the environment is still very minimal and $33.7 \%$ is influenced by the perception of ecological threats. The results of material expert validation show that the product developed has a score of 4 for relevance; 4.5 for accuracy; 4 for completeness of dishes and materials, 3.5 for curiosity; 4.5 for interaction encouragement; and 4 to encourage employees to build their knowledge (scale 1-5). The results of the media expert's validation show that the product developed has a score of 4 in the presentation of the application; 3.5 for language and typography; and 4 for functions and benefits (scale 1-5). So that an android-based environmental education program for employees in the Citarum river basin was developed as a model for environmental education recommendations. Currently educitarum application installation is still done manually, by looking at the response and test results to factory employees, it is expected to utilize the play store as a digital distribution service operated and developed by Google which is also the official application store for the android operating system so that it is more accessible to the public and easier to install the application. The recommendation of this study is as one of the media of environmental education for the community, especially employees who are around the citarum watershed, with the hope that insights about the environment will increase and pro-environmental behavior will also change.

\section{REFERENCES}

[1] A.M. Ruepert, K. Keizer, \& L. Steg, The relationship between Corporate Environmental Responsibility, employees' biospheric values, and proenvironmental behavior at work. "Journal of Environmental Psychology", 54, 65-78. 2017.

[2] A. Kollmuss \& J. Agyeman, Mind the Gap: Why Do People Behave Environmentally and What are the Barriers to Pro-Environmental Behaviour. "Environmental Education Research", 8(3), 239-260. 2002.

[3] M. Pothitou, R.F. Hanna, \& K.J. Chalvatzis, Environmental knowledge, pro-environmental behavior, and energy savings in households: An empirical study. "Applied Energy", 184, 1217-1229. 2016.

[4] S.D. Wihardjo, S. Hartati, Y. Nurani, \& A. Sujarwanta, "The effects of green schooling knowledge level and intensity of parental guidance on the environmental awareness of the early age student". 12(5), 251-257. 2017.
[5] R. Retnowati, R. Istiana, \& E. Suhardi, Pengembangan Model Pocket Book Berbasis Kekayaan Lokaldalam Peningkatan Perilaku Ramah Lingkungan Siswa Sma Negeri Kota Bogor. "Jurnal Pendidikan Indonesia", 4(4), 1-6. 2004.

[6] Arizco, 2010

[7] Y. Yu, X. Yang, \& K. Li, E ff ects of the terms and characteristics of cadres on environmental pollution: Evidence from 230 cities in China. 232(October 2018), 179-187. 2019.

[8] H.C. Tsai, M. Jou, J.Y. Wang, \& C.C. Huang, An empirical study on the incorporation of APP and progressive reasoning teaching materials for improving technical creativity amongst students in the subject of automatic control. "Computers in Human Behavior", 75, 997-1007. 2017.

[9] Galuh Puspita, 2014

[10] H. Kurniawan, T.S. Jaya, Desain dan Implementasi Mobile Kuliah di Politeknik Negeri Lampung Berbasis Teknologi Android. "Jurnal Ilmiah ESAI". 2016;10(1):46-56.

[11] V. Cazalis \& A. Prévot, Are protected areas effective in conserving human connection with nature and enhancing pro-environmental behaviors? Biological Conservation, (December 2018), 1-8. 2019.

[12] A. Meloni, F. Fornara, \& G. Carrus, Predicting pro-environmental behaviors in the urban context: The direct or moderated e ff act of urban stress, city identity, and worldviews. Cities, 88(December 2018), 83-90. 2019

[13] J. Zhang \& R. Huang, Journal of Hospitality and Tourism Management Employees ' pro-environmental behaviors (PEBs) at international hotel chains (IHCs) in China: The mediating role of environmental concerns (ECS). "Journal of Hospitality and Tourism Management", 39(June 2018), 129-136. 2019

[14] D.T. Chen, T. Lin, Bin, J.Y. Li, \& L. Lee, Establishing the norm of new media literacy of Singaporean students: Implications to policy and pedagogy. "Computers and Education", pp. 1-13. 2018.

[15] Y. Yulianti and Hartatik, Pentingnya Media Pembelajaran Berbasis Entrepreneurship. "Jurnal Pemikiran Dan Pengembangan Sekolah Dasar", 1(4), 1-6. 2014

[16] D. Darmawan, "Mobile learning sebuah aplikasi teknologi pembelajaran". Jakarta: Rajawali Pers. 2016

[17] T. Georgiev, E. Georgieva, and A. Smrikarov, Me-Learning: A new stage of E-Learning. "Proceedings International conference on Computer Systems and Technologies, CompSysTech' 2004", IV.28, 1-5. 2004.

[18] C. O’Malley, G. Vavoula, J. Glew, J. Taylor, M. Sharples, \& P. Lefrere, Guidelines for learning/teaching/tutoring in a mobile environment. Mobilearn project deliverable. Available from http://www.mobilearn.org/download/results/guidelines.pdf. 2003.

[19] R.D. Anggraeni and R. Kustijono, Pengembangan media animasi fisika pada materi cahaya dengan aplikasi flash berbasis android. "Jurnal Penelitian Fisika Dan Aplikasinya (JPFA)”, 3(1), pp.11-18. 2013 